\title{
State Expansion, Insurgent Resistance, and Territorial Control in Arauca 2002-2010
}

\author{
Por Charles Larratt-Smith ${ }^{1}$
}

I

$n$ recent years, international security experts have warned against the threat posed by 'ungoverned spaces' insofar as these swaths provide a natural sanctuary to insurgents, criminals, and international terrorists alike 2 . However, when the state expands into these 'lawless zones' in order to pacify them, the results are hardly the same across space and time. This state expansion will often witness a reduction in violence mirrored by an improvement in stability and order. Quite frequently however, violence will increase as stability and order worsen. The fact that state expansion into ungoverned spaces produces such different results across areas of extremely close proximity begs the following research questions: how is the state able to establish control, and, by extension, order in some contested spaces more easily than others? What enables insurgents to withstand and survive this massive onslaught in some cases while failing in others? And at last, how and why does this variation in violence and order occur?

* $\quad$ Artículo recibido en febrero Abril de 2016.

Artículo aprobado en mayo de 2016.

1 Candidato a doctor de la Universidad de Toronto en el Departamento de Ciencia Política.

2 Immediately following the attacks of $9 / 11$, then-President Bush declared that US security was threatened more by failing states than conquering ones. Just over one year later then-CIA director George Tenet emphasized the serious threat posed by 'ungoverned areas', 'lawless zones', and 'veritable no-man's lands' in a Worldwide Threat Briefing. When running for the presidency in 2007, Barack Obama reiterated the threat posed by 'impoverished, weak, and ungoverned states' which were 'fertile breeding grounds for transnational threats' (Raleigh \& Dowd, 2013: 1). 
Since 2002, the Colombian state has embarked upon a massive state expansion project in many volatile areas of the country which were previously controlled and governed by other armed non-state actors. This projection of military, bureaucratic, and economic power into these contested spaces has not necessarily brought peace and stability with it, casting into doubt the efficacy of the central government's larger attempt at state expansion. Perhaps nowhere is this more evident than in the department of Arauca. Having served as a laboratory for the Colombian government since 2002, while also being home to various armed non-state actors, this department testifies to the mixed results which accompany state expansion projects at a micro-level across disparate municipalities such as Arauca, Arauquita, and Tame. For example, the incursion by the Colombian military in Arauca municipality witnessed a permanent decline in violent deaths, forced displacement, and armed actions from 2002 until 2010 and beyond, an accomplishment which was also mirrored by the virtual expulsion of armed insurgents from the municipality. Meanwhile, Arauquita and Tame experienced initial increases in the same indicators of violence, while ultimately witnessing no real improvement over the same period of time. Interestingly enough, whereas armed nonstate actors retained a virtual hegemony in Arauquita, the municipality of Tame remained split between a core area controlled by the state and their paramilitary allies, while the periphery remained under insurgent control $^{3}$.

It appears that the Colombian state's ability to reclaim and reduce the violence in certain key physical spaces in Arauca was the result of external-local elite alliances which succeeded in disrupting the linkages between civil society, local politics, and armed insurgents, thereby, enabling them to attain territorial and administrative control of Arauca

The region of Tame where the state re-established control is geographically and historically linked to the plains region of Arauca, whereas insurgents maintained a consolidated presence in the piedmont region of the municipality. 
municipality and large parts of Tame. Violence therefore was greatest in contested areas where the state and other armed actors pursued disparate interests and goals, and where the former could neither fully control, nor ultimately force local populations into collaborating regardless of the level of control they exercise. This is especially true in those areas where: (a) local civil society - and by extension the civilian population - possessed robust levels of embeddedness (e.g. horizontal intra-civilian ties) coupled with a strong capacity for collective action, (b) local elites or other ready-made allies were in short supply, and (c) armed nonstate actors were firmly anchored in local social networks and, hence, possessed a high level of population control.

While offering no specific model or theory, this article will highlight several causal explanations which shed light on how the state is able to recuperate certain territory in contested spaces, while in others insurgents are able to successfully resist such efforts. Importantly, some of these discoveries throw into question other well-established explanations found in the larger literature in the study of micro-level violence in civil wars. First, rationalist-based explanations of civilian collaboration in contested zones fail to account for other socio-historic factors which may facilitate or impede cooperation with armed actors in particular spaces $^{4}$. The assumption that violence is contingent on control of territory and the level of collaboration that armed groups obtain from local populations is correct to a degree; however, it is clear that the latter consideration is of paramount importance to the potential success or failure of state expansion. The degree of territorial control does not always produce a commensurate level of collaboration and information which is required to defeat opposing actors, as recent history is wrought with examples where territorial hegemons in contested spaces found local cooperation (and reliable intelligence) extremely hard to obtain despite their overwhelming dominance. Similarly, armed groups with weaker levels of territorial control have been able to prevent such 
civilian collaboration quite effectively due to other local endogenous mechanisms. As demonstrated by these particular case studies, high levels of embeddedness between civilians and insurgents as well as intra-civilian ties at the local level can make the cost of collaboration or defection to the state substantially higher and, hence, unfeasible or unappealing, regardless of the potentially personal risks they may assume for non-compliance with any actor who has the greatest degree of control within said space.

Second, the study of social networks between armed actors and civilian populations has advanced quite recently. However the most significant research can only explain insurgent capacity to operate militarily at the national level, and as the Colombian case demonstrates, there is dramatic variation at the sub-national level between disparate units of the same insurgent organizations ${ }^{5}$. Of equal importance, the assumption underpinning much of this scholarship interprets relations between the state and armed non-state actors - of whatever ideological stripe - as inherently confrontational and prone to lethal interactions. Non the less, recent literature focusing on civil wars where there are multiple actors operating and interacting in a myriad forms highlights an important, yet, perhaps, inconvenient truth: seemingly implacable enemies at the national level do not always seek to kill one another at the local level. Furthermore, relations between disparate armed actors in a civil war are dynamic and will often differ among members of the same groups in different spaces depending on immediate local goals and objectives ${ }^{6}$. Recent conflicts all over the globe have demonstrated a tendency to be "frequently characterized by bargains, deals, and norms that structure patterns of violence" between oft-shifting constellations of alliances (Staniland 2012: 255). This naturally presents a massive challenge to the central premise of most work on state expansion and modern counterinsurgency.

$5 \quad$ See Staniland (2014), and Sarbahi (2014).

$6 \quad$ See Idler (2012), and Bakke, Gallagher, and Seymour (2012). 
Finally, the Araucan insurgency poses problems for the replicability of the theory that armed rebels who depend on rents available from extractive industries are somehow more predatory or abusive towards civilian populations because they have no need to solicit funds from local taxes or donations and are, hence, 'detached' from local considerations such as fair treatment ${ }^{7}$. The wide array of finances available to insurgent groups through extractive industries such as hydrocarbons and the formal mining sectors can actually strengthen relations with local civilian bases if they channel these resources back into the communities in the form of social services and public works. Furthermore, if insurgent groups do not depend on local individual contributions to finance their operations, peasants will tend to perceive them in a more favorable light than in other contested regions where rebels are forced to tax local residents living within their area of $\mathrm{control}^{8}$.

In sum, the theoretical frameworks which one would expect to shed light into the variation of violence, and by extension the capacity of the state to recuperate contested territory, do not sufficiently account for the disparate levels of violence and order found in contiguous spaces shared by the same armed actors such as the Colombian department of Arauca. While there are nascent literatures on the fluidity of inter-group relations and the role of social networks on armed actor embeddedness, these have not yet been sufficiently developed to account for this variation in areas of close proximity.

\section{A Brief History of Arauca: Pastures to Petroleum}

In order to understand Arauca, it is imperative to distinguish between the dual histories of the sub-region: that of the plains (la Sabana), and that of the piedmont (el Sarare). Each micro-region shares a common geography and broader history, two factors which are integral

See Humphreys and Weinstein (2006), and Weinstein (2006).

See Gutiérrez Sanín (2008). 
to understanding the dynamics of conflict which emerged there later. Whereas the former sub-region can be found in the municipalities of Arauca, Cravo Norte, Puerto Rondón, and the southeastern of Tame, the latter is located between the municipalities of Arauquita, Saravena, Fortul, and the western and northern parts of Tame.

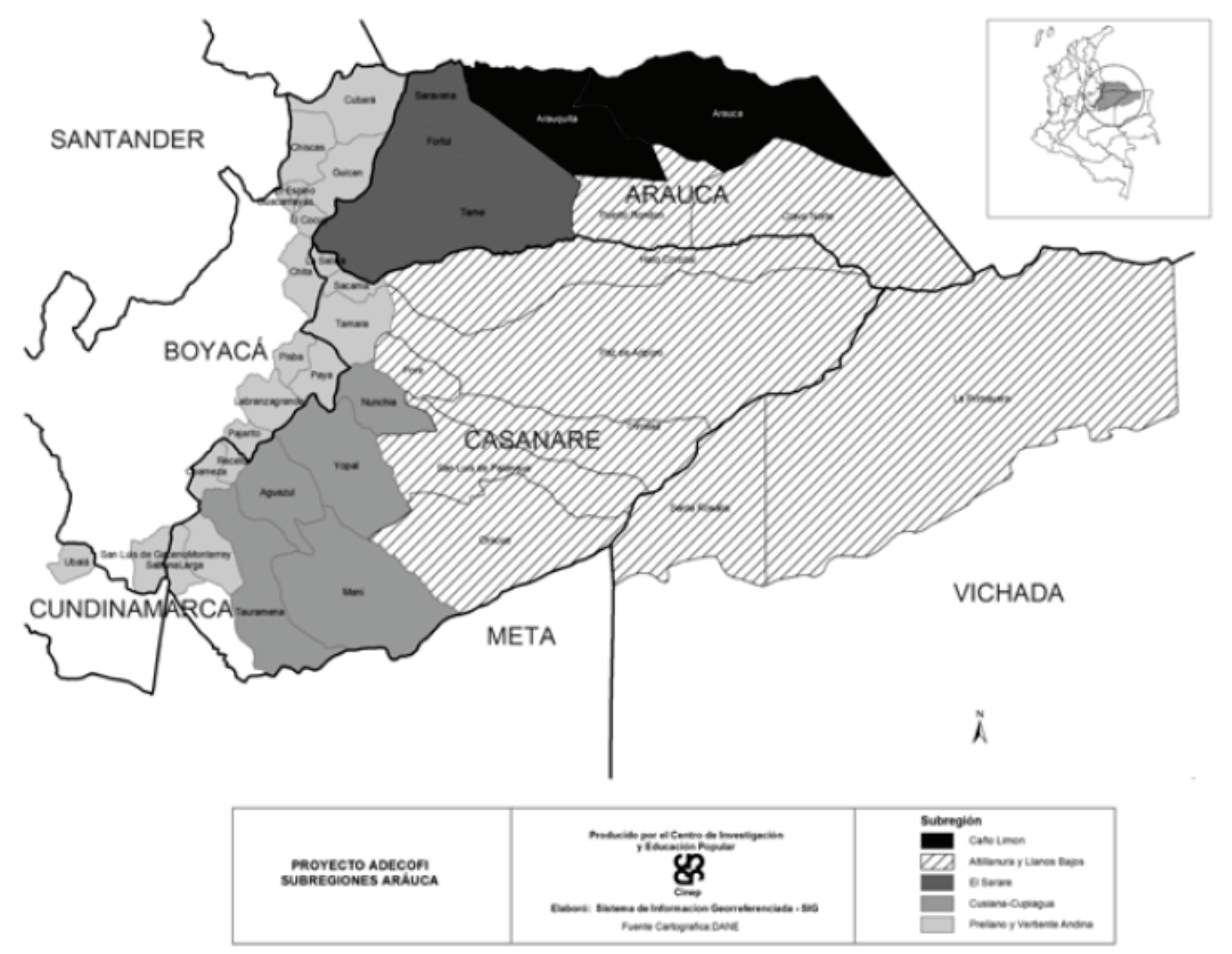

The plains region is the traditional Arauca, settled before the 17th century and largely administered by Jesuit missions in both Arauca and Tame. Historically, the plains have been devoted to the raising of cattle and little else. The piedmont, on the other hand, is the 'new' Arauca, whose process of settlement more recently occurred following the end of la Violencia in the early 1960s, and whose migrants arriving from neighboring departments such as Boyacá, Santander, and Norte de Santander, were encouraged by the state to engage in subsistence farming 
on small, family held plots of land.In the early years of this period, local governance in the region was practically non-existent, as the entire intendency of Arauca was officially administered from the city of Sogamoso in eastern Boyacá. While intendencies were officially administered by executively appointed intendants, the Araucan political elite was thoroughly dominated by the Liberal party, which was principally composed of a group of wealthy cattle ranchers from the plains region. These elites exercised power through clientelist linkages with core constituencies primarily found in Arauca municipality and Tame. In reality, however, the department during this juncture was more heavily incorporated into neighboring Venezuela than it was with the rest of Colombia. Furthermore, despite the intended efforts of INCORA and other official entities to assist and help develop the colonization zone in the piedmont and the plains region, these measures fell drastically short due to the negligence of the Colombian government ${ }^{9}$.

Into this authoritative vacuum stepped a tiny nucleus of guerrillas from the Ejército de Liberación Nacional (ELN) in 1966, forming the core of what would eventually become one of the strongest guerrilla units in Colombia: the Domingo Laín front. Originally organizing and recruiting colonos in the piedmont region between Saravena and Tame, the Domingo Laín front eventually came to fulfill many of the fundamental tasks of governance in the entire piedmont region in the glaring absence of the Colombian state. However, these efforts alone were often not sufficient to meet the demands of the expanding migrant population in the piedmont region, which by the 1970s had outgrown that of the plains region ${ }^{10}$. Faced with a plains-dominated political elite that was unable or uninterested in investing in basic public goods and services in the piedmont region, local habitants in Saravena in 1972 collectively mobilized five thousand protestors and launched a civil strike - the first of its kind in Latin America - which ultimately forced the national

See Carroll (2011: 180).

10 See Gutiérrez (2010). 
government to the negotiating table and more importantly, gained the mobilization much needed concessions from INCORA. The success of this early mobilization had enormous ramifications for the future of Araucan civil society.

Over the course of the 1970s, piedmont society orbited around two pillars of social organization: local civil society-primarily in the form of the Juntas de Acción Comunal and peasant associations such as the Asociación Nacional de Usuarios Campesinos (ANUC) and the Federación Nacional Sindical Unitaria Agropecuaria (Fensuagro)- and nascent guerrilla units. It is crucial to underscore that these two pillars were not mutually exclusive; rather; dense linkages existed between them ${ }^{1112}$. However, despite being a guerrilla zone, the ELN only registered its first attack against the Colombian state in Betoyes, Tame, in 1981, some fifteen years after arriving in Arauca. A year prior, a small group of insurgents from the Fuerzas Armadas Revolucionarias de Colombia (Farc) migrated from the interior and organized the Guadalupe Salcedo front in the piedmont, establishing their presence in the larger region by initiating a military attack upon its arrival in Fortul ${ }^{13}$. While the early 1980 s

11 A former mayor of Arauquita (Interview 13, Arauquita, 2016) describes this era: "Antes ¡había 5 policías para todo el municipio!, la guerrilla era la que arreglaba los problemas de las infidelidades, las ventas de las fincas, todo. Aquí el Estado no llegaba."

12 All interview participants will appear anonymously in order to protect their identities. These interviews were conducted separately in the municipalities of Arauca, Arauquita, Saravena, Fortul, Tame, and in the Colombian capital, Bogotá D.C., between January and July 2016.

13 The Guadalupe Salcedo front eventually came to be known as the 10th front, while the Farc also established the 45th front in the western part of Tame and Fortul later on. It is important to note that both the ELN and the Farc maintained clearly distinct zones of influence in the piedmont - and later the entire department with the former guerrilla group exercising hegemony in the border region with Venezuela and the western parts of Fortul and Tame, while the latter insurgency occupied the rural interior of Arauquita, Fortul, and Tame. However, these zones of influence were not the exclusive domain of either group, as one interviewee (Interview 4, Arauca, 2016) referred to the town of Puerto Jordan in Tame as an 
marked the beginning of insurgent engagement with official authorities in Arauca, this tension increased exponentially with the arrival of oil multinationals and foreign contractors such as Occidental Petroleum and Mannesmann AG in the 1982-1983 period which came to explore and eventually start producing large quantities of petroleum for export from the Caño Limón oil field in northwestern Arauca municipality.

The discovery of hydrocarbons and the subsequent conversion of Arauca from a backwater, agricultural and cattle ranching zone largely controlled by armed guerrillas, to a major oil producing center naturally brought about a belated investment from the national government in the region. This was mirrored quite predictably by an increase in demands and complaints from local constituents about the negative social and environmental effects of oil production on adjacent communities. Drawing on a proven repertoire, local civil society in the piedmont and beyond mobilized repeatedly during this period to demand concessions and improvements in basic services for their communities ${ }^{14}$, while both guerrilla groups started to engage more frequently with the Colombian police and military stationed in the region. The tension caused by the presence of multinationals was reflected in the twenty day occupation of Saravena's airport by some ten thousand protestors in 1982, followed by massive occupations of Arauca municipality's main square for weeks at a time; all these in order to force intendential and national level authorities to grant concessions such as the construction of a much belated interdepartmental highway. These mobilizations became a constant feature of Araucan society well into the new millennium ${ }^{15}$.

example of this bifurcation of space: "Ese era un caserío de una sola calle, y cada uno de los límites de la calle pertenecían a cada guerrilla, una fila de casas de las Farc y un fila de casas del ELN.”

14 This sentiment is widely shared in the department. A leading trade unionist at the Unión Sindical Obrera de la Industria de Petróleo (USO), the main oil workers union in Colombia, elucidates: "Siempre, siempre con las petroleras llega la violencia. Cuando comenzó la explotación aquí hubo plata de las petroleras para la insurgencia." (Interview 8, Arauca, 2016).

15 Carroll (2011). 
Thus, the introduction of oil transformed Arauca from a marginalized, forgotten corner of Colombia into an integral economic center of extraction in a short period of time, bringing with it not only foreign investment, but also a massive increase in government presence in the form of the National Police and the armed forces. While the oil field was located principally in Arauca municipality, the reserves extracted at this site were transported to the Caribbean port of Coveñas some 780 kilometers away via the construction of the Caño Limón-Coveñas oil pipeline during this time period, an effort which required a huge military expansion into the intendency. Whereas increasingly the majority of the regions' population lived in the piedmont, the lion's share of Arauca's royalties were under the purview of the presidentially appointed intendential supervisor and the Arauca municipal council, given that Caño Limon was located primarily in this municipality. However, access to these substantial royalties soon shifted dramatically in favor of both piedmont civil society and both insurgent groups with the democratic opening which occurred over the course of five years between 1986 to 1991, a period which ushered in not only a new constitution, but also permitted the direct election of municipal representatives, mayors, and governors for the first time in Colombian history.

While linkages already existed between both the armed insurgency and the piedmont civil society through both rebel groups sponsorship of different national-level peasant organizations in Arauca (ELN - ANUC; Farc Fensuagro), this electoral reform gave both groups the ability to intervene directly in the management at the municipal and departmental level by fielding and supporting political candidates and parties in local elections beginning in the mid 1980s and early 1990s. Faced with the voting potential of the demographically larger piedmont electorate, the traditional political elites from the plains - specifically, from Arauca municipality - began to sponsor nascent paramilitary groups as early as 1988, while simultaneously encouraging military repression of the political left in order to prevent a dramatic departmental reconfiguration ${ }^{16}$. Despite the rise

16 Interview 21, Saravena (2016). 
in repression (extrajudicial homicides, torture, forced disappearances), by the early 1990s the political map of Arauca had been redrawn with almost all key political positions held by candidates hailing from political parties beholden to one of the two insurgent groups and a constellation of piedmont civil society organizations. Even the old guard political elites from the plains forged new alliances with these new electoral powers so that they could continue to have access to public coffers swelled by the massive influx of oil royalties ${ }^{17}$. Thus, by the early to late 1990s, while ostensibly separate, the linkages between Araucan civil society, the ELN and the Farc, and the municipal and departmental level governments, were quite dense if not stronger than in any other guerrilla controlled region of Colombia ${ }^{18}$.

For this reason, both the top military brass in Bogotá and paramilitary chiefs in northwestern Colombia specifically targeted Arauca as fertile ground for expansion in the late 1990s and early 2000s. Perceived as a guerrilla haven, rich in oil and strategically located near an important transit corridor with Venezuela for drugs, arms, and other contraband, it provided an obvious target for the implementation of the revamped official military strategy under Plan Colombia ${ }^{19}$. Similarly, the paramilitary

The first fiscal year that oil royalties became available to the intendency's government in 1986-1987, Arauca's budget increased twenty fold, initiating a period of lavish public spending and endemic corruption that has lasted until the present (Carroll, 2011).

18 Arauca is a unique case insofar as the insurgent groups, who historically were prone to preventing local communities under their control from participating electorally, competed with one another in municipal and departmental elections (Farc supported the Patriotic Union party, whereas the ELN attached itself to a faction of the Liberal party) with relatively low levels of violence between them. Termed 'armed clientelism', the guerrillas (primarily the ELN) attempted to export this model of social and political integration to other regions in order to consolidate territorial control, albeit with varied success outside of Arauca (Peñate, 1998). Occidental Petroleum lobbied the passage of Plan Colombia in U.S. Congress, receiving an annual $\$ 98$ million earmark for American military assistance in guarding the Caño Limón-Coveñas oil pipeline and other infrastructure in the region. U.S. contractors were directly involved in the infamous 1998 Santo 
group, Bloque Vencedores de Arauca, entered the department via Tame in 2001 in collusion with the Colombian Army's 18th Brigade and unleashed a wave of selective assassinations and massacres against perceived allies of the insurgents - namely leftist politicians, community leaders, and peasants who happened to live in certain 'guerrilla' zones - primarily in the plains region of Tame, Puerto Rondón, Cravo Norte, and Arauca municipality. The paramilitary incursion succeeded in claiming control of the plains region of Arauca, but ultimately failed to permanently weaken either the ELN or the Farc in the department. In reality, these paramilitaries were only able to establish a presence in southern Arauca before demobilizing in 2005. Quite simply, the guerrillas were too strong for them in northern Arauca. In order to achieve a feat of that magnitude, a much larger conventional force would be required ${ }^{20}$.

Upon taking office in 2002, President Álvaro Uribe took full advantage of the military aid and assistance provided by the United States under Plan Colombia and unleashed an unprecedented military offensive against armed non-state actors - primarily leftist guerrillas - operating beyond the purview of the central government in Bogotá21. During this time, "the patterns of the past began to be broken and, finally, the national government began to have effective control of the entire nation" (Kline, 2009: 5). At the onset of his first term, Uribe launched numerous military initiatives by Decree 1837 to reclaim the most violent areas of the country which were contested by guerrillas and paramilitaries alike. Two zones of rehabilitation and consolidation were established: one constituting

Domingo bombing in Saravena, where a Colombian warplane bombed a civilian village, killing some 18 civilians in the process (Amnistía Internacional, 2004).

20 See Monografía Político Electoral (2008).

21 The robust joint-security agreement between Colombia and the United States, while initially conceived and outlined as an antidrug strategy in 1999, changed suddenly 'in the blink of an eye' after September 11th, 2001, as Plan Colombia "started to morph into a counterterror and counterinsurgency strategy" representing a drastic reprioritization of interests and goals on the part of the Colombian state (Sweig 2002: 124). 
three municipalities in Arauca, and the other encompassing fifteen municipalities in Montes de María ${ }^{22}$. In these areas, the military operated with emergency powers ostensibly with the aim of re-establishing and maintaining public order, as Arauca effectively served as the guinea pig for Uribe's eventual nationwide military and state expansion project ${ }^{23}$. The local military unit in Arauca, the $18^{\text {th }}$ Brigade of the Colombian army, saw its forces increased from 5766 to 7839 soldiers between 2002 and 2004. It was also fortified by the creation of the Mobile Brigade No. 5, which was established specifically to carry out counterinsurgency operations in extremely unnavigable terrain in the department. Existing military bases were expanded while new installations were constructed to expand the presence of the military to every municipality in the department in order to protect vital infrastructure ${ }^{24}$.

The implementation of the zone of rehabilitation and consolidation in Arauca saw President Uribe use his executive authority to strip the then-governor, elected in 2002, of his position due to supposed ties with insurgent groups, and to replace him with a military appointee until new elections could be convened in 2003. In the week before the 2003, municipal and departmental elections, numerous candidates representing piedmont social bases in the mayoral and gubernatorial elections across the department were arrested again for supposed ties to the insurgency, allowing Uribe's allies to win crucial elections throughout Arauca ${ }^{25}$. Simultaneously, the massive increase in military presence in Arauca beginning in 2002 was accompanied by a spike in human rights violations, most notably against civil society leaders,

22 While the three northern municipalities of Arauca, Arauquita, and Saravena were specifically targeted under this Decree, according to numerous interview participants, the militarization of Arauca included every municipality in the department without exception. The former Colombian president "used \{Arauca\}, rich in oil and sharing a border with Venezuela, as a testing ground for many of his key policies on security" (Amnestía Internacional 2004: 1).

23 See Leal Buitrago (2003); Defensoría del Pueblo (2003).

24 Gutiérrez (2010).

25 Interview 14, Arauquita (2016); Interview 47, Bogotá D.C. (2016). 
hundreds of whom were arrested arbitrarily in massive sweeps and illegally detained without due process based on the testimony of anonymous informants. The Colombian government had succeeded in breaking the vital linkages between electoral politics, civil society, and the insurgency in the department ${ }^{26}$. While Uribe and the military's strategy was to 'take the water from the fish', Araucan civil society had already begun to publicly distance itself from the insurgency at this juncture, most notably the Farc, who was increasingly engaging violently with both the Colombian armed forces and the civilian population after the breakdown of their failed peace negotiations with the government in 2002. The fumigation campaign initiated by the armed forces in Tame, Fortul, Saravena, and Arauquita in 2003 added even more pressure to the already strained relations between the Farc and local populations in these areas, the latter of whom bore the brunt of the state's response to the coca boom fuelled by the former ${ }^{27}$. Finally, while the expansion of state presence succeeded in reducing attacks to oil infrastructure in the department - the widely perceived priority of the massive intervention in the region - and in temporarily weakening the linkages between Araucan civil society, armed insurgents, and local politics, it did not ultimately succeed in disrupting guerrilla hegemony in the piedmont ${ }^{28}$.

26 Uribe also stripped the departmental government of its ability to control its own budget and resources. Effectively speaking, the national government had complete control of (a record amount) of oil rents (Interview 8, Arauca, 2016).

27 Only the Farc encouraged Araucan peasants to cultivate coca and the effects of the fumigation on these rural communities was profound. A local woman in Fortul remembers: "A la gente no le avisaron que la iban a fumigar y era muy difícil que las aspersiones no arrasaran con todo. Esa fumigación acabó con todo, con el plátano, con la yuca, con todo" (Interview 22, Fortul, 2016). The ELN has historically distanced itself from the drug trade and as a result this was one factor of many which led to both groups engaging in all-out conflict between 2005 and 2009 in the department.

28 This can be seen most evidently in the massive decline in guerrilla attacks on the Caño Limón-Coveñas pipeline (a key guerrilla tactic to extort the oil multinationals) which dropped precipitously from an all time high of 170 attacks in 2001 to a mere 17 by 2004 (United States Government Accountability Office 2005). 
Whereas the Colombian government made serious in-roads against the insurgents in the period 2002 to 2005, the latter year ushered in perhaps the most deadly era of the armed conflict in Arauca. Despite the fact that the regional paramilitary block demobilized in 2005, the security situation in the department was about to worsen ${ }^{29}$. With almost all seats of political and economic power firmly under the control of Uribe and his allies, and civil society distancing itself from the insurgency, long standing tensions between ELN and Farc fronts in the department finally boiled over and both groups engaged in an all-out war. While the reasons included territorial disputes, leadership disagreements, outstanding debts, and the division of rackets, the result was the fiercest ever confrontation between these two particular guerrilla groups in the history of the Colombian conflict. In a Faustian twist, both groups ended up making convenient alliances with separate emerging factions of the demobilized paramilitary block while the ELN even went so far as to forge an unholy arrangement with local commanders of the Colombian military in order to destroy the Farc in Arauca once and for all ${ }^{30}$. The exact toll of the conflict is estimated to be upwards of 1,000 casualties on all sides with some 50,000 civilians displaced, with both insurgent groups devastating local civil society in a lethal tit-for-tat series of reprisal killings of community leaders perceived to have loyalties to one side or the other ${ }^{31}$.

Eventually both groups reached a rapprochement in 2009-2010, ending hostilities and again co-governing the piedmont municipalities. Their

29 Of an estimated 1000 paramilitary fighters in its ranks, only 207 combatants formally participated in the demobilization process in late 2005. Many of the remaining members formed neo-paramilitary organized criminal groups known as 'Bacrims' and solely focused on illicit economic activities in the larger sub-region (Carroll 2011).

30 See the following article for more on this surprising temporary alliance between the ELN and the Colombian military in Arauca: Revista Semana, "Cómo el Ejército se alió con el ELN en Arauca” (01/19/2009) http://www.semana.com/nacion/ articulo/como-ejercito-alio-eln-arauca/99226-3

31 Interview 14, Arauquita (2016). 
timing to end their conflict was opportune as the uribista governor of Arauca, Julio Acosta Bernal, had turned fugitive in 2008 after his longstanding ties to local paramilitaries were exposed, and his ideologically similar successor was forced out of office in 2011 for corruption ${ }^{32}$. Uribe himself ended his second and final term in office, and current President Juan Manuel Santos has pursued a markedly less bellicose approach in regards to the counterinsurgency, particularly since the initiation of the ongoing peace process with the Farc in 2012. This 'relaxation' of the conflict in Arauca has permitted both insurgent groups to slowly regain their social, political, and military hegemony in the department. ${ }^{33}$

Today, the Araucan piedmont remains one of, if not the most, guerrilla consolidated sub-regions of Colombia, as well as being the most militarized by the Colombian armed forces, whose presence throughout the department is ubiquitous. In sum, after the fall from grace of Uribe's political allies in Arauca, as well as the resolution of the inter-guerrilla conflict, the linkages between the insurgent groups, formal electoral politics, and civil society have slowly been rebuilt, although not quite to what they were prior to the election of Uribe in 2002. However, the department remains heavily occupied by the Colombian armed forces, thereby leading to an uneasy co-existence between all the armed actors present.

\section{Evaluating Belligerent Control in Arauca: Empirical Challenges to Establishing armed Actor Presence at a Micro Level}

When the state massively expanded its presence in Arauca in 2002 with the intention of expelling the guerrillas once and for all from their beachhead in north-eastern Colombia, its strategy of breaking the linkages

32 Julio Acosta Bernal was eventually captured, tried, and sentenced to 40 years in prison for his role in the paramilitary murder of a local government official in Arauca.

33 Interview 1, Bogotá D.C. (2016). 
between the insurgent groups, local politics, and Araucan civil society was largely successful throughout the department ${ }^{34}$. Yet, as local military officials and political elites would soon discover, defeating the guerrillas completely was a different task altogether, one which would remain incomplete by the time Álvaro Uribe left office in 2010. In Arauquita, any illusion of progress was exactly that: a temporary illusion which was quickly belied by the harsh reality of the conflict in Arauca. However, in municipalities such as Arauca and Tame, this counterinsurgency project appeared to have succeeded, albeit with notable variation in the level of success achieved between the two ${ }^{35}$. Upon closer inspection of the violence statistics of these plains municipalities over the course of this time period, it may seem that although the state was able to reclaim a majority of territorial control in Arauca municipality and a modicum in Tame, the subsequent levels of violence varied dramatically between them, thereby throwing into the question the overall efficacy of the intervention into these 'pacified' spaces.

A lawyer at the Defensoría del Pueblo in Arauca (Interview 2, Arauca, 2016) says that "con la declaración de la Zona de Rehabilitación y Consolidación la intención del Estado era exterminar a los grupos armados organizados ilegales que hacían y hacen presencia en la region", while a longtime Saravena activist claims that Uribe wanted to "eliminar el teijdo social de la guerrilla."(Interview 16, Saravena, 2016). Uribe himself stated publicly at the beginning of the Zone of Rehabilitation and Consolidation that the guerrillas would be expelled from Arauca in three months time (Interview 21, Saravena, 2016). "Arauca tiene límites con Casanare, Boyacá y Santander. Tame es el centro de gravedad donde se irradia el poder para la comunicación tanto hacia Boyacá y el interior del país, como hacia Casanare y Santander.” (Interview 47, Bogotá, 2016) 

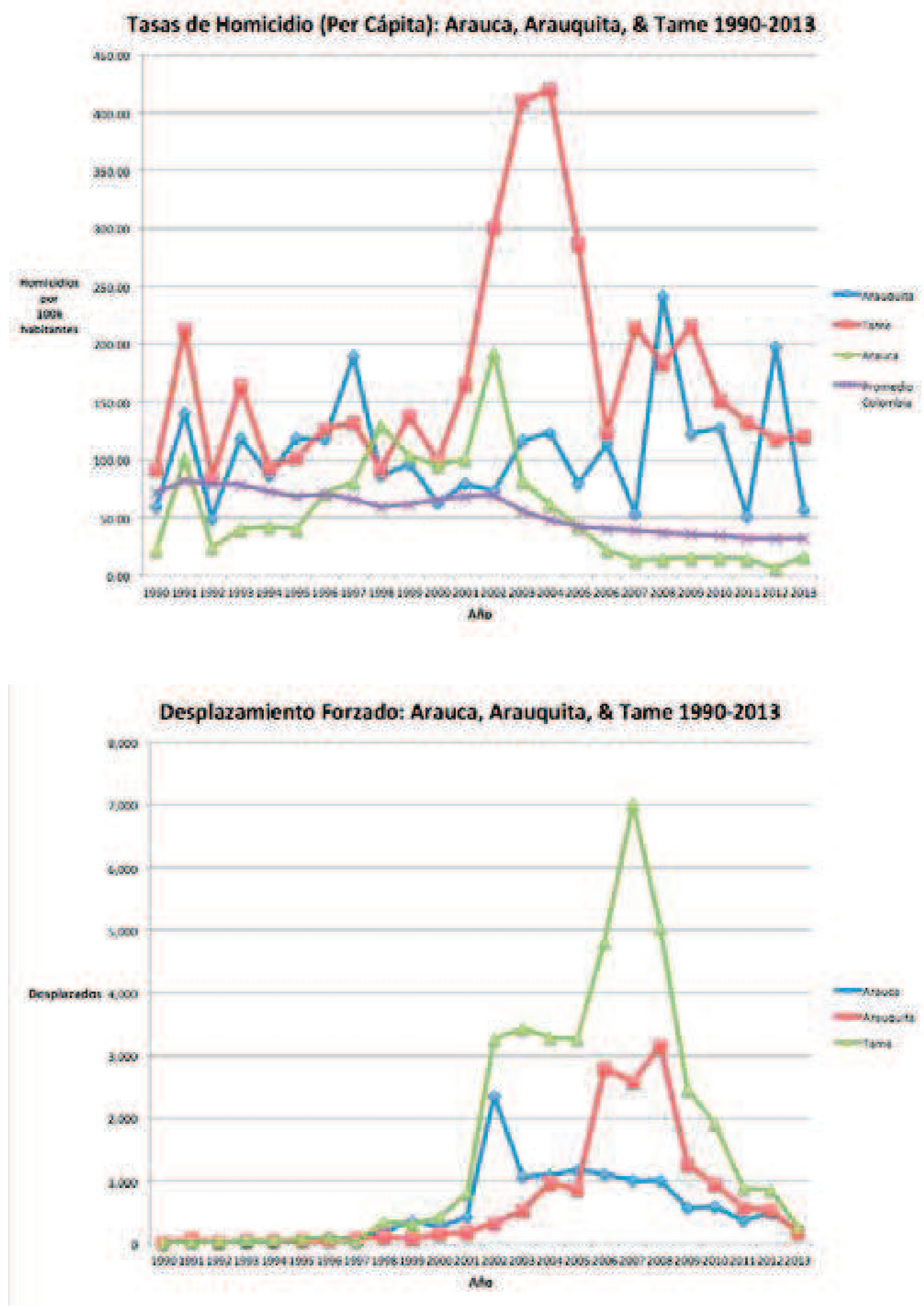

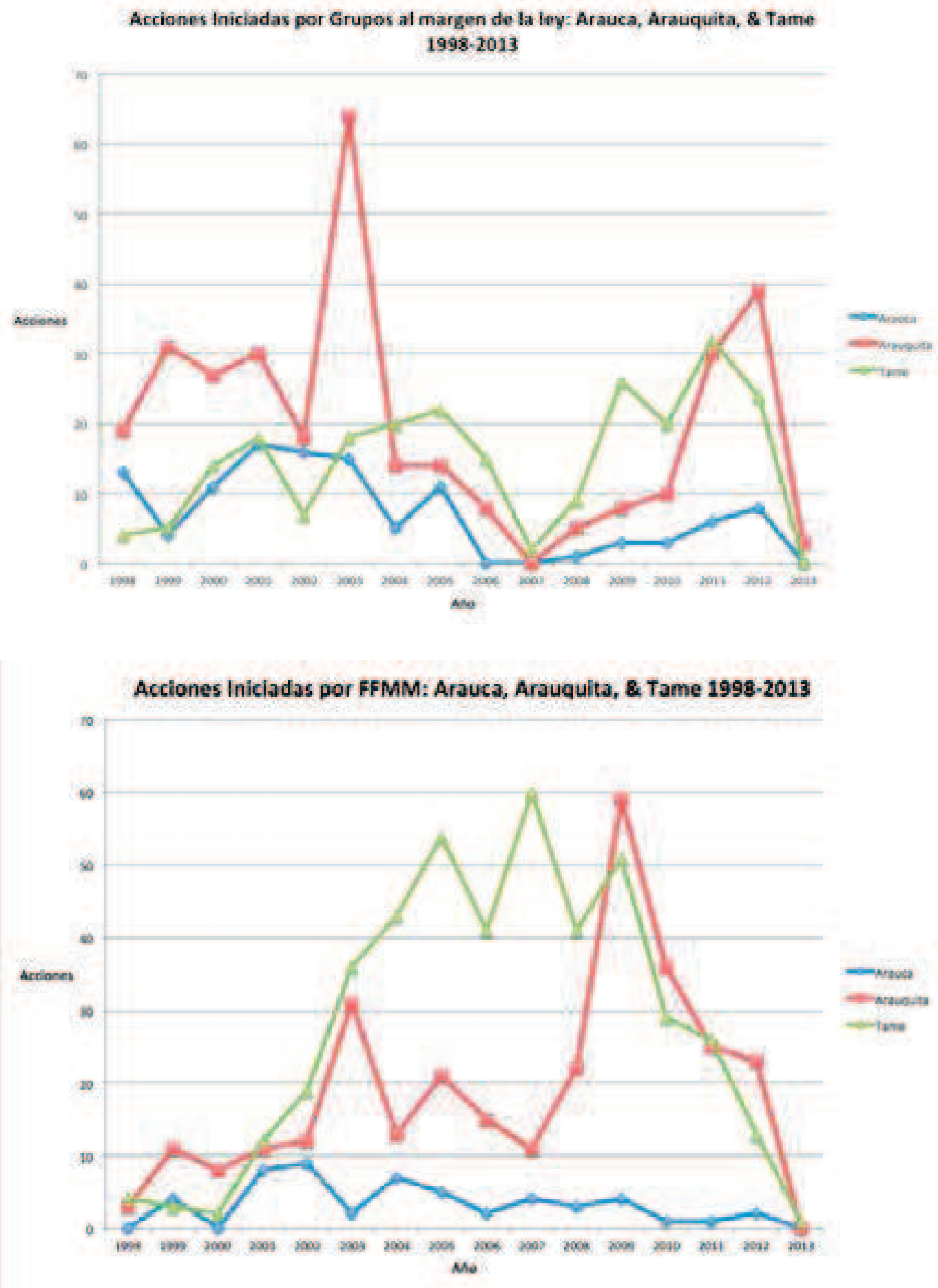

Fuente: Observatorio del Programa Presidencial de Derechos Humanos y Derecho Internacional Humanitario de la Vicepresidencia de la República. http://www.verdadabierta.com/cifras/5295-estadisticas-homicidio 
A rough yet accurate idea of the level of control exercised between actors can be attained by comparing triangulating qualitative interviews with local residents with data sets on both violent actions initiated (i.e. armed combats, ambushes, bombings against military objectives, etc.), and infractions of international humanitarian law (i.e. assassinations, disappearances, threats against non-combatants) committed at the municipal level by the military, the insurgents, and the paramilitaries. Violent actions demand a higher level of logistical coordination from armed groups; hence, when an actor consistently registers these actions in a given municipality over a sustained period of time, it is demonstrative of a relatively consolidated presence.
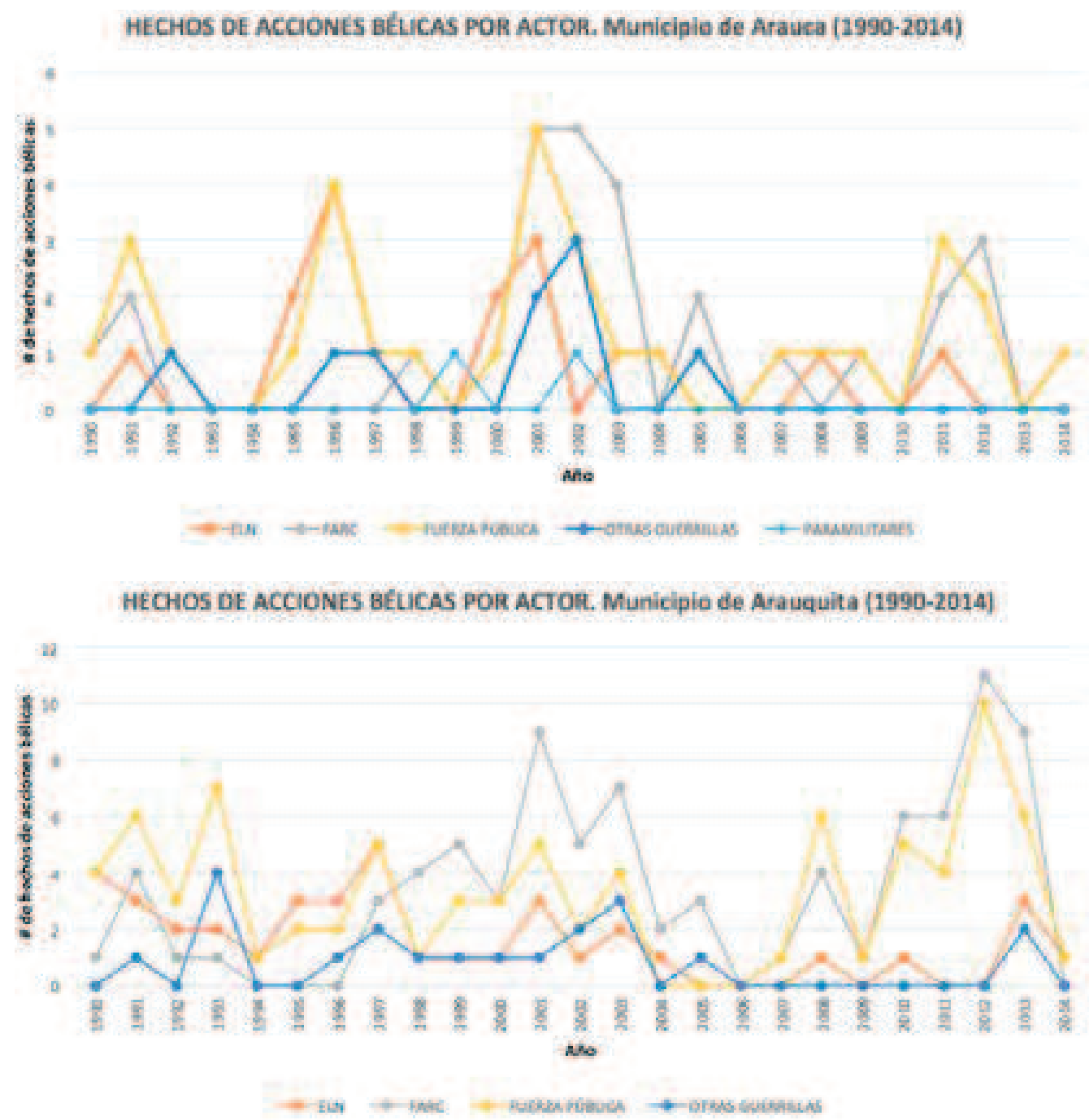


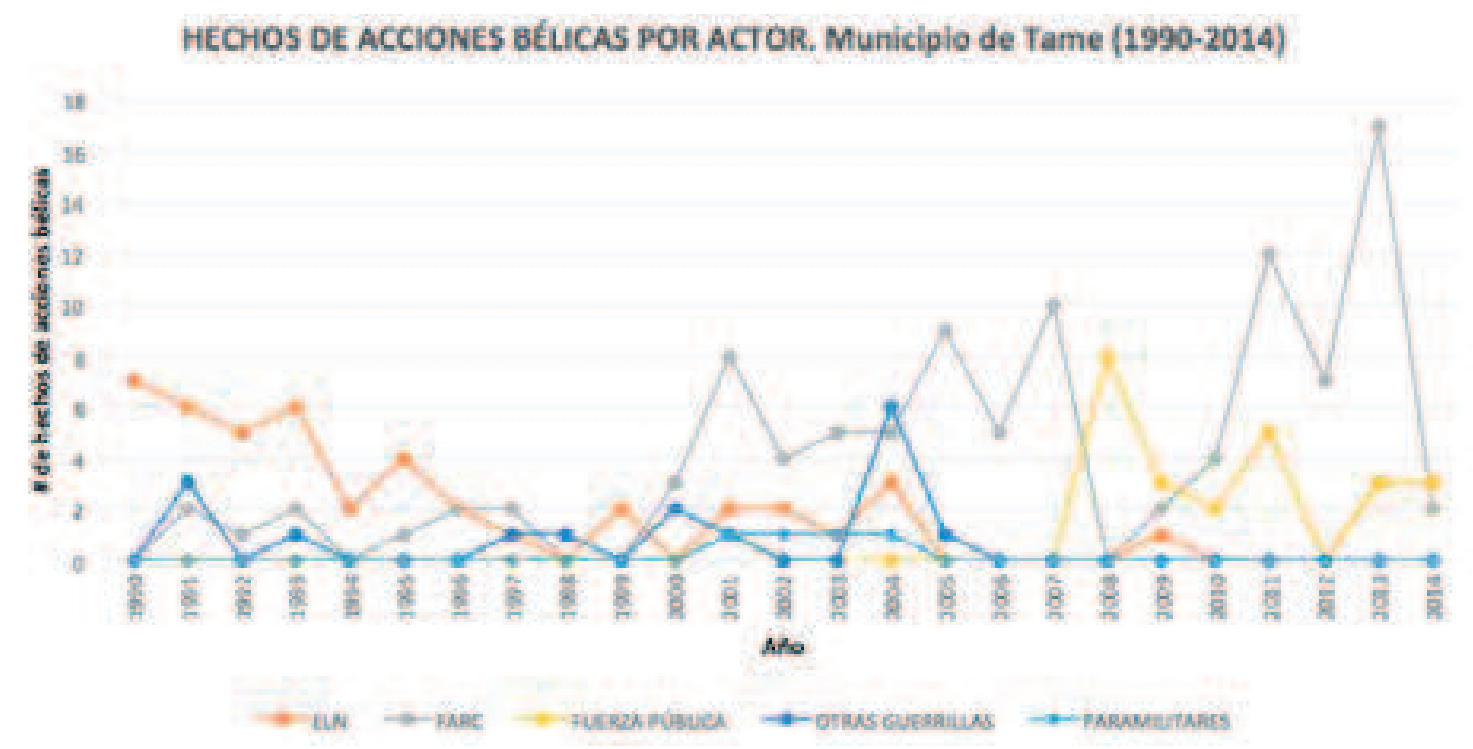

Similarly, infractions of international humanitarian law committed by a specific actor in a particular space indicate either an attempt to gain further control/prevent further loss of territorial control (as per Kalyvas's model), or is quite simply a reflection of the modest coercive capacity of an actor within said territory. The above graphs show the levels of violent actions and infractions of international humanitarian law committed by various actors at the municipal level and should engender a better understanding of the presence and capacity of each respective actor in these three municipalities.

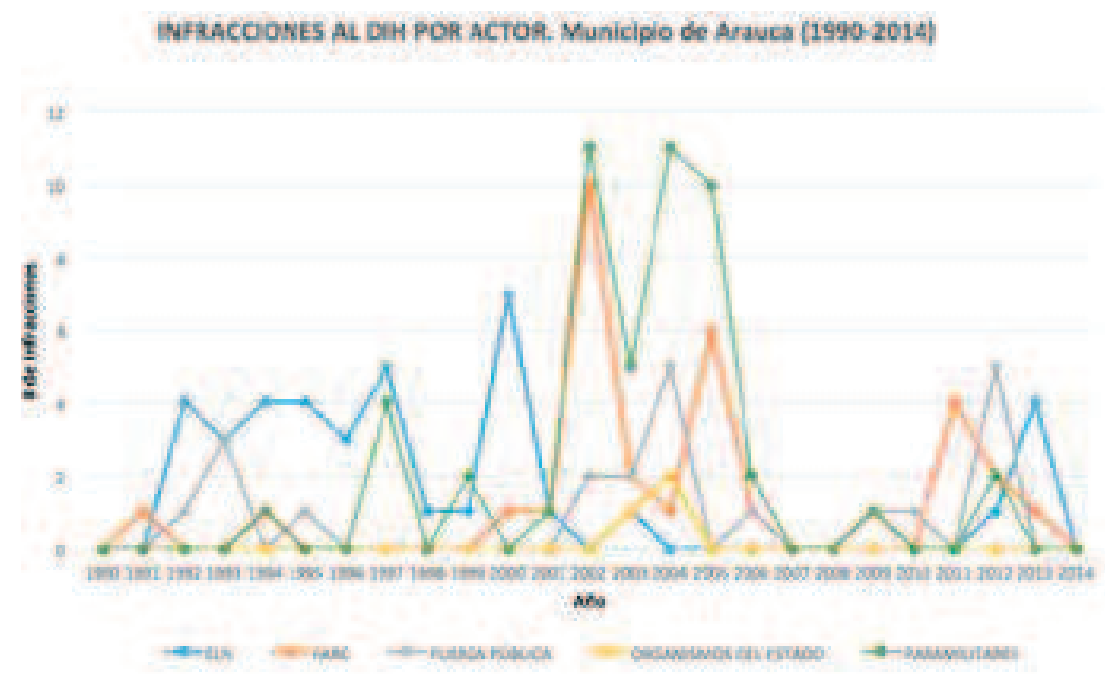



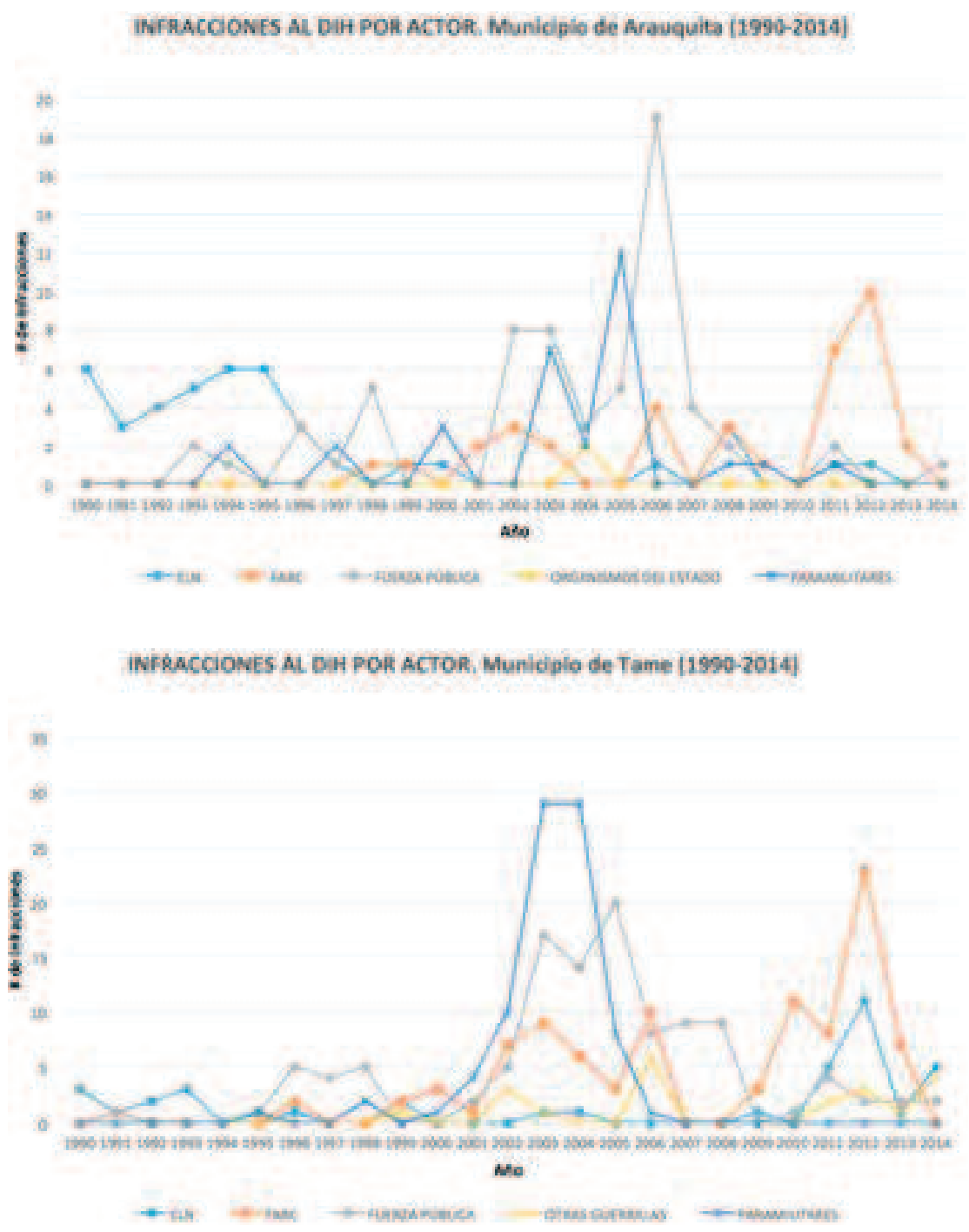

Fuente: CINEP-PPP Banco de Datos

Firstly, it is crucial to note that paramilitaries registered violent actions in Arauca municipality and Tame during this period, the significance of which is that the presence of the Bloque Vencedores de Arauca must have been substantially stronger, and more permanent in both of these municipalities between 2001 and $2005^{36}$. Generally speaking, paramilitaries

36 "Cabe advertir que la presencia paramilitar en Arauca fue limitada y su afianzamiento fue rápidamente contrarrestado por la guerrilla en zonas neurálgicas del territorio, y que su desmovilización contribuyó a cerrar, de alguna 
tend to have a constant presence in places where they have military support, and insurgents do not have a substantive presence. Conversely, paramilitary units tended to avoid, or were unsuccessful at directly penetrating and establishing a presence in zones where insurgents have a strong degree of influence ${ }^{37}$. The task of direct confrontation with the guerrillas is instead carried by the military, as the primary function of paramilitary groups in said theatres of war is "poder desarrollar operativos de represión contra la población civil e implementar un modelo

forma, un ciclo de violencia” (Gutiérrez 2010: 21). The pattern of behavior of the paramilitaries in Arauca municipality and Tame are remarkably similar as per the available violence statistics and participants interviews. Their incursions occurred with the complicity of the armed forces, as often members from both groups did not wear uniforms as to disguise their true identities. Massacres, selective assassinations of perceived 'leftist sympathizers', forced displacement, and violent threats increased substantially with the arrival of the Araucan paramilitary block in these the plains region between 2001 and 2003 (Interview 25, Tame, 2016; Interview 4, Arauca, 2016;). And in both cases when they attempted to enter the piedmont municipalities - Fortul from Tame, and Arauquita from Arauca municipality and Puerto Rondón - they were violently repelled by the insurgents and local civilian populations due to the successful security cordon established by the former group. Thus, paramilitaries were only every able to infiltrate the piedmont individually or in small numbers, either in disguise or protected by the army or the police, and upon arrival their activities were limited to issuing threats and the occasional selective assassination (Interview 13, Arauquita, 2016; Interview 16, Saravena, 2016). A local human rights activist in Saravena clarifies this territorial distinction of paramilitary behavior: "En las zonas de la sabana hicieron presencia como ejército, en las zonas del piedemonte las modalidades de operación fueron diferentes, había sicariato.” (Interview 21, Saravena, 2016)

However, this does not mean that the guerrillas were entirely absent from Arauca municipality and Tame, as both of these graphs demonstrate that the Farc registered a high number attacks in these two municipalities after 2010, thus suggesting that they are still present and active in these locations. In the case of Arauca municipality, the guerrillas lacked any active camps within the municipality after 2005, however they still supposedly have militants active in urban centers. Both the ELN and the Farc are still capable of making incursions and attacking key targets in and around the capital from neighboring Arauquita (Interview 47, Bogotá D.C., 2016). Tame on the other hand still possesses active combatants from both insurgent groups, although they have been largely confined to the periphery of the municipality, near the mountains to the west, and close to the border with Fortul and Arauquita in the north and east (Interview 12, Arauquita, 2016). 
de Guerra contrainsurgente en la que el paramilitarismo ha demostrado ser un instrumento eficaz". This objective is achieved through the "eliminación física, la desaparición y el desplazamiento forzado de los dirigentes y de sus bases sociales", each of which constitutes a violation of international humanitarian law (González, Bolívar, and Vásquez, 2003: 61). Violations committed by paramilitaries in Tame, Arauquita, and Arauca municipality spiked dramatically between 2002 and 2005, occurring simultaneously with increases in both with high levels of violent actions and infractions of international humanitarian law committed by the military in these municipalities, thereby conforming with the aforementioned logic of state-paramilitary symbiosis.

Secondly, while the Colombian armed forces already maintained a presence in every municipality in Arauca prior to the implementation of Uribe's counterinsurgency strategy in the department, their coercive capacity improved markedly beginning in the 1999-2001 with the technological, logistical, and financial support offered by Plan Colombia, and by extension the U.S. military ${ }^{38}$. As the above graphs demonstrate, the military maintained and exercised an aggressive capacity in the three municipalities of focus, however much as the continued violent actions of the insurgents in Arauca municipality and Tame during this time period obscured their reduced presence in those places, the same applies for the Colombian state in Arauquita. However, the persistence of violations of international humanitarian law committed by the military in Arauquita and Tame well into the Uribe's second term suggest that the armed forces continued to struggle to territorially consolidate a firm presence in these municipalities ${ }^{39}$. While it clearly possessed -

38 Interview 47, Bogotá D.C. (2016).

39 While some posit that the Colombian military faced enormously problems locating and inflicting damage on the insurgent groups in Arauca during this juncture, and, hence, ended up causing more harm to local civilian populations, others have highlighted the successes of the military in capturing and killing high ranking guerrillas - primarily from the Farc - in Tame, Fortul, and Arauquita (Interview 18, Saravena, 2016; Interview 12, Arauquita, 2016; Interview 47, Bogotá D.C., 2016). Interview 1, Bogotá D.C. (2016); Interview 47, Bogotá D.C. (2016). 
and continues to possess - resources and manpower superior to the guerrillas and maintains a presence in each municipality in Arauca, the ability of the armed forces to exercise control outside of their bases and beyond heavily fortified spaces in urban centers is a different matter altogether and one which is extremely difficult to measure methodologically speaking.

Finally, the level of violent actions by all groups appear to have declined from 2004-2005 until 2009-2010, a temporary reduction which can be interpreted in several ways in this particular context. Whereas the first few years of the state expansion in the department witnessed a predictable spike in armed confrontation between the armed forces and the insurgents, by the middle of this decade both guerrilla groups reduced their attacks against the state considerably for three primary reasons: the superior technological capacity of the Colombian military, the tentative discussions over peace negotiations between the ELN and the Uribe administration, and the all-encompassing conflict which erupted between the ELN and the Farc between 2005 and 2009. The first factor, coupled with the relentless pressure of the military's counterinsurgency campaign in Arauca, forced a strategic and tactical reevaluation by guerrilla commanders in the department and, hence, a reduction in violent actions on their part ${ }^{40}$. Meanwhile, the second and the third factors directly relate to the historically alternating pattern of negotiations between successive Colombian presidents and various insurgent groups, and the longstanding tensions between the ELN and Farc which finally boiled over into direct confrontation in $2005^{41}$. An interesting pattern to note is the far more bellicose nature of the Farc during this period than the ELN, a tendency which was a dramatic reversal from the previous twenty years. This fact is also reflected in the level of violations of international law committed by the Farc throughout these Arauca municipality, Arauquita, and Tame between 2002 and 2010, as while they are much lower relative to those

$41 \quad$ See Alderid Gutiérrez Loaiza (2012).

42 Interview 15, Arauquita (2016); Interview 14, Arauquita (2016). 
authored by both the armed forced and the paramilitaries, they stand out in comparison to the ELN. The fact that the Farc was the primary objective of the counterinsurgency campaign throughout the larger country, coupled with the insurgent group's notable rupture with its historic social bases at this juncture can explain this empirical trend. ${ }^{42}$

\section{Explaining State vs. Insurgent Success: Historic Residues, Civilian-Elite Defection, \& Insurgent Embeddedness}

The period preceding 2002 saw strong vertical linkages established between both the ELN and Farcand the local civil society and politics. Such was their influence that the Araucan insurgents effectively decided which candidates were going to compete in elections for leadership positions in the juntas de acción comunales, and mayoral and gubernatorial offices ${ }^{43}$. Local elites in the plains forged alliances with these candidates in order to continue to benefit from massive oil royalties, while occasionally sponsoring nascent paramilitary activities yet to no great effect. The Colombian military attempted to combat the insurgency, yet faced enormously difficulty in this task because of the lack of available allies needed to consolidate territorial control, especially in light of the guerrillas privileged position in the larger department ${ }^{44}$. With

$43 \quad$ "Vertical ties are created by relations of information, trust, and belief that link organizers to local communities. These ties can be used by organizers as they try to build or sustain political, economic, or social projects in these communities." Whereas "horizontal ties link people across space and connect different geographic and social sites. They are formed between mobile individuals drawn from beyond a single social and geographic locale." (Staniland 2014: 21-22)

44 Prior to 2002, the Colombian military's only real allies in Arauca were certain plains elites, the oil multinationals, and the Venezuelan government. However, the official position of Venezuela towards the Colombian conflict changed dramatically in 1998 with the election of Hugo Chávez, as Venezuelan authorities ceased to cooperate with their Colombian counterparts and insurgents were able to operate with minimal interference in border refuges such as Apure, Táchira, and Zulia. 
the massive overhaul of the Colombian armed forces beginning with the implementation of Plan Colombia in 1999, coupled with the dramatic new strategic direction of the Colombian counterinsurgency unleashed by Álvaro Uribe in 2002 upon taking power, the vertical linkages which the guerrillas exercised over local civil society and politics were severed dramatically ${ }^{45}$. The electoral arena became the domain of the plains elites, who had defected from their previous alliances by transforming themselves into uribista allies, forging strong horizontal linkages with the military, paramilitaries, and the oil multinationals ${ }^{46}$.

Simultaneously, in the face of this massive shift in the departmental balance of power to the state, the historic bond between the insurgent groups and piedmont civil society was severely ruptured by the increased level of violence directed at the latter by the former. In essence, both the guerrillas and civil society had been isolated, both facing the full weight of the counterinsurgency campaign implemented in Arau$\mathrm{ca}^{47}$. It is integral to note that despite this rupture between the two, the guerrillas never deserted their civilian bases to bear the full brunt of the military and the paramilitary's offensive in the piedmont, while the civilian population never defected from the insurgent groups to the state in the region over this period of time ${ }^{48}$. Finally, while both the

alcaldías. Hubo inversiones de la OXY, inversiones de la gobernación e inversiones de USAID \{United States Agency for International Development\} para la realización de operaciones cívico militares realizadas para 'mitigar el daño colateral de la guerra'”" (Interview 8, Arauca, 2016).

A local accountant for the Department of Public Works in Arauca describes the fickleness of these political and plains elites: "Los políticos araucanos son aliados del poder de las armas para conservar el poder político. Muchos se arrimaron al árbol que mejor sombra daba en momentos específicos, en Arauca hay mucho oportunismo político.” (Interview 24, Saravena, 2016). Interview 1, Bogotá D.C. (2016); Interview 47, Bogotá D.C. (2016). It is important to note that the ELN maintained far better relations with their civilian bases during this period in comparison to the Farc according to numerous local inhabitants (Interview 14, Arauquita, 2016). 
guerrillas and Araucan civil society were increasingly isolated in the years following 2002, they were able to sustain their continued efforts by locating and establishing horizontal linkages with new allies outside of the department: Venezuelan authorities in the state of Apure in the case of the insurgents, and national and international NGOs and advocacy groups in the case of Araucan civil society.

The dramatic re-configuration of Arauca's social networks beginning in 2002 thus leads to a couple of very interesting questions: how and why did the civilian population - and civil society at large - in the piedmont not defect to the state in the face of an immensely difficult situation? Faced with increasing repression from all armed actors, why did the piedmont civilian population decide to stay loyal to the insurgents instead of simply defecting to the state as was the case in the plains region of Arauca? And how did the rebels from the same guerrilla units survive this massive onslaught in the piedmont, but not the plains during this juncture in time?

The answer to this puzzle can be attributed to the strength of intracommunity ties at the local level. Quite simply, the civilian population did not jump ship in the piedmont region because strong intra-civilian linkages impeded a large-scale defection to the state, an occurrence which the armed forces required in order to militarily defeat the insurgents. I posit that the high degree of intra-civilian ties in the piedmont region of Arauca is the product of a collective identity tied to the origins of many migrants for settling in the sub-region, the extreme isolation of this population from the rest of Colombia prior to the discovery of oil in 1982-1983, the historically antagonistic, and often violent, relation between the state and local inhabitants over the course of the 1980s and 1990s, and the positive effect of sustained mass mobilizations on intra-civilian relations.

The high level of embeddedness between civilians in the piedmont can be traced back to the historic development and presence of civil society 
in the larger department of Arauca. Prior to the democratic opening in Colombia in the late 1980s and early 1990s, political identities and loyalties in the piedmont were borderline non-existent as many settlers had fled some of the most intense partisan conflicts of la Violencia in nearby departments such as Boyacá, Santander, and Norte de Santander, and were thus anathema to the idea of a state which did not protect them and the traditional parties which had rendered them victims ${ }^{49}$. The isolation in which these settlers found themselves, with little to no support from the intendential or national governments until oil was discovered in the region in 1983, only compounded these socio-political identities. In such an environment where self-sufficiency and collective action are requisites for the survival of the local population, it is, therefore, unsurprising that a comprehensive and highly unified civil society emerged in Arauca during this period of time ${ }^{50}$. This is evident in the sustained level of polarized confrontation with the state and the massive commitment of local inhabitants to such public acts of collective action for three decades preceding the massive state intervention in $2002^{51}$.

A Saravena union leader describes this high level of embeddedness: "Hay que resaltar de la región que hay un buen potencial organizativo de la gente. Aquí la gente se asocia y se organiza y hay un gran capital humano." (Interview 17, Saravena, 2016) This fact is reflected in the incredible number of formal local associations and organizations found in Arauca during this time. A cursory account suggests that Araucan civil society in 2002 consisted of 57 cooperatives and peasant organizations, 14 labor organizations, 7 civic organizations, 1 student organization with seven local chapters, 2 indigenous associations, 1 regional peasant association and branches of 2 national peasant organizations, 570 civic action committees, 7 municipal associations of civic action committees, 1 departmental association of civic action committees, 2 human rights committees, and local representation of many national level NGOs (Carroll 2011).

51 "Así, en 2002, el mapa de actores y organizaciones sociales era bastante complejo y muy variado en la expresión de los distintos intereses. Además, en los diez años anteriores, se forjaron o acentuaron procesos organizativos ligados a formas de autogestión a través de organizaciones comunales, asociaciones de trabajos agrícolas, cooperativas de productores y, posteriormente, a formas de organización sindical, que dieron origen a un entramado social con apreciables niveles de cohesión.” (Gutiérrez 2010: 25) 
The strength of intra-civilian linkages, or embeddedness as this concept has been refashioned by Granovetter (1985), are integral to outcomes ranging from the economic productivity of immigrant communities in the developed north (Portes 2010), to the success of post-war recovery efforts (Colletta and Cullen 2000). However, although there is a plethora of literature discussing the role of these linkages in enabling disparate outcomes in a variety of contexts, there are few convincing explanations about how embeddedness is produced at the individual or group level. Drawing on recent work by Levitsky and Way (2013), the strength of intra-civilian ties in this sub-region of Colombia can be described in similar path dependent terms as the resilience of revolutionary party structures elsewhere in the world:

"Violent conflict also enhances elite cohesion by strengthening partisan identities and hardening partisan boundaries...intense polarization sharpens "us-them" distinctions, strengthening within-group ties and fostering perceptions of a "linked fate" among party cadres. Where cadres have participated in prolonged violent struggle, they are more likely to view party membership in "moral" terms, and to frame choices about cooperation or defection in terms of loyalty rather than a simple material calculus. The polarization generated by revolutionary wars often persists into the postrevolutionary era, effectively "trapping" potential defectors within the ruling party. When the opposition can be credibly linked to historic enemy and when abandoning the ruling party is viewed as disloyalty or even treason, the cost of defection will be high." (9)

While Araucan civil society never directly engaged the Colombian state militarily at any juncture in time, the dynamic which emerged between local habitants in the piedmont and official authorities during this period is remarkably similar to ruling party cadres in revolutionary states, with strikes and mass protests employed instead of armed confrontation. The polarization which already existed between the region's inhabitants and the state was heightened in 2002 with the introduction of controversial military programs designed to draw civilians into 
the conflict by collaborating directly via military service (Soldados de mi pueblo), or by providing information to authorities for a reward (la red de cooperantes). These initiatives indicated to the local public that they were expected to collaborate and by extension defect to the state $^{52}$. However, piedmont civil society "refused to accept the borders (us-them) that separated official institutionality and the enemies of the state” (Gutiérrez 2010: 27).

This polarization has been known to foster higher levels of embeddedness among groups which are frequently engaged in confrontation with other groups perceived to be more powerful, and whom, as a result, suffer discrimination and a lack of alternative socio-economic opportunities $^{53}$. A frequent complaint of piedmont residents is the guerrilla stigmatization they are branded with, a grievance which bears very real and, often, lethal consequences for individuals carrying documentation identifying them as such ${ }^{54}$. Similarly, given the vastly superior resources of the capital in comparison to the other municipalities in the department, the long-standing division of oil royalties overwhelmingly in favor of Arauca municipality is a major historical point of contention between the department's residents as well ${ }^{55}$. Finally, the effect of the massive arrests by the Colombian military in the piedmont appeared

53 See Portes and Sensenbrenner (1993).

54 A frequent complaint heard in the piedmont municipalities complained is this stigmatization of being guerrillas, as many residents were not able to leave their hometowns between 2001 and 2005 due to the paramilitary practice of setting up illegal roadblocks where many piedmont habitants were detained and then summarily executed merely for possessing an ID card which stated they were from Arauquita, Saravena, or Fortul (Interview 20, Saravena, 2016; Interview 15, Arauquita, 2016).

55 From the discovery of oil until the present, all royalties in Arauca have been divided amongst the municipal and departmental governments in the following manner: Arauca department (77.9\%), Arauca municipality (15.5\%), Arauquita (6.1\%), Saravena $(0.4 \%)$, and Tame $(0.1 \%)$ (Sarmiento 2015). This massive disparity in royalties is most keenly felt by Arauquita's residents: "Cuando eso pasó había que definir los límites entre Arauca y Arauquita, supuestamente Caño Limón debía dividirse 50-50 y eso no pasó, De las regalías a Arauquita le correspondió 
to be far more counterproductive than the state anticipated. The deeply unpopular dragnet arrests and arbitrary detentions which became a regular occurrence early on in the establishment of the rehabilitation and consolidation zone only served to harden the civil population's resistance to the state expansion and made potential collaboration then much more unlikely ${ }^{56}$.

Decades of collective action in the form of mass mobilizations forged robust social linkages between neighbors, not to mention with the insurgent groups operating throughout the piedmont ${ }^{57}$. Hence, for both the ELN and the Farc, surviving the massive state-paramilitary expansion in the department did not demand the full loyalty and collaboration of civilian bases; rather, the key was simply for this demographic not to defect to the state, something which non-combatants did in the plains region of Arauca but not in the piedmont. Despite the increased use of repression by the insurgents against civilians, the option they provided was widely perceived as more conducive to local interests than the state's option, which was largely viewed as subordinate to the prerogatives of both the plains and external elites. Of equal importance,

solamente el 10\%. Mientras tanto, la OXY tapó ríos, tumbó monte y provocó un terrible daño ambiental.” (Interview 12, Arauquita, 2016)

56 The most notorious example of this occurred on November 12th, 2002, when some 2000 civilians from all walks of life were arrested and summarily detained in a local soccer stadium in Saravena, while anonymous informants gradually identified supposed collaborators of the insurgents for the authorities. The net result of this dragnet operation was four permanent convictions for collaboration with the insurgency (Interview 21, Saravena, 2016).

57 The high level of collective action is frequently credited for the local quality of life, a sentiment reflected in the comments of an educator and community organizer in Fortul: "Todo lo que tenemos en la región en temas de salud y educación se ha logrado aquí gracias a los paros y las movilizaciones." (Interview 23, Fortul, 2016) In the twenty year period between 1982 and 2002, there were upwards of a dozen major mobilizations throughout the department which drew thousands of Araucans which met with varying degrees of success in terms of their demands. For more on the history of social mobilizations in Arauca, see Leah Carroll (2011). "By late 2008 Araucan social movements were strong, extremely well networked, 
the insurgents were credited with having prevented the entrance of the Bloque Vencedores de Arauca into the piedmont region, thereby sparing the civilian population of the atrocities committed by paramilitaries against non-combatants elsewhere in the department and country, whereas the military was seen as a complicit partner of said actors. Finally, the relative lack of local economic elites in the piedmont prevented the state from locating ready-made allies to help facilitate the success of the state expansion project; this makes a notable difference from the plains region where local elite defection was key to the recuperation of territory previously held by the guerrillas.

Thus, this embeddedness subsequently prevented widespread defection among piedmont residents to either the paramilitaries or the state. Even when local citizens had been shut off from formal electoral politics, and both insurgent groups were brutalizing civil society leaders, civilians in the piedmont did not defect en masse to the other side when the situation became bleak, as so often was the case in other contested regions in Colombia during this period of time. The historical-social effects of being isolated for so long prior to the discovery of oil forced citizens in the piedmont to depend upon one another to articulate their rights and demands in the form of mass mobilizations which demanded an enormous level of coordination and commitment with minimal freeriding. Even at the height of the ELN-Farc conflict in 2008, Arauca civil society remained impressively cohesive ${ }^{58}$.

In the plains regions, on the other hand, these mobilizations were less frequent, and intra-civilian relations were largely dictated by cattle ranching,

unified with respect to social movement actions, and extraordinarily successful. This was despite the radical reversal of regional autonomy that decimated the electoral left and broke long-standing Left-elite alliances, the concerted attack from government forces augmented by U.S. military aid, and a late but deadly wave of paramilitarism." (Carroll 2011: 228) 
the historic basis of the local economy. Hence, social linkages between inhabitants in Arauca municipality and the plains region of Tame were characteristic of patron-client relations between the large landholders/ cattle ranchers and their employees, who were entirely dependent on their bosses for their livelihoods ${ }^{59}$.

Another crucial factor in explaining the inability of the Colombian state to convince or coerce piedmont residents to defect from the insurgents was the difficulty it found in offering a better, more viable alternative to guerrilla rule in the sub-region. Whereas both the ELN and the Farc's presence and activities in the plains region were seen as detrimental and predatory to local elite interests well before Uribe came to power in 2002, the state was, and still is viewed in the same light in the piedmont region ${ }^{60}$. This sentiment owes much to the state's historic absence

comparing Tame and Saravena, a former army general and commander of the 18th Brigade in Arauca explains non-elite/elite defection in the following terms: "Tame es un municipio con una tradición histórica desde la independencia, de gente buena, sana. Es un municipio muy antiguo, entonces ellos tienen un sentido de pertenencia muy superior a los de Saravena. Saravena fue una colonización de gente que llegó, colonos de toda parte del país, especialmente huyendo de la violencia, mucho delincuente llegó allá a buscar... entonces el origen de la población es muy diferente. Su idiosincrasia es muy diferente. El Comandante que no analice esos fenómenos, de pronto se equivoca a la hora de combatir un problema. Entonces el caso de Saravena, es un municipio creado por el gobierno con colonos de diferentes partes del país y de ahí nacieron los problemas muy profundos. Porque allá llegó gente que estaba huyendo de la justicia. Tame no... entonces fue mucho más fácil porque la gente colaboró más, la gente sentía más su sentido de pertenencia de su municipio, por ser raizales de allá, colaboraron más con el Ejército." (Interview 47, Bogotá D.C., 2016).

60 Omar Gutiérrez reiterates this relationship: "En el plano social, tanto el ELN como las Farc, establecieron una fuerte relación con sectores subordinados de la población civil que creían ver en ellos intermediaries fundamentalers frente al Estado central y a las empresas petroleras...” (2011: 13). A local human rights activist from Fortul adds: "Los combatientes de las Farc y del ELN son hijos del pueblo, y son víctimas del Estado y del petróleo. El pueblo odia al ejército y a odia a la policía, aquí ellos compran a los niños, abusan sexualmente de las mujeres; y ellos, los policías y los militares, le tienen miedo al pueblo: salen más bien poco.” (Interview 19, Saravena, 2016).

${ }_{61}$ Interview 12, Arauquita (2016); Interview 47, Bogotá D.C. (2016). 
in Arauca until the discovery of oil, a turning point which was rapidly followed by the militarization of the department by the Colombian armed forces ${ }^{61}$. During this period, the state's key priority was the protection of oil infrastructure and little else, a prerogative which retained primacy for successive Colombian presidents until the present day ${ }^{62}$. As previously mentioned, the majority of residents in the piedmont did not directly benefit from the massive influx of oil royalties in the department relative to their plains neighbors, even though the strong linkages between the insurgents, civil society, and departmental politics enabled large increases of investment in local development (e.g. infrastructure, services, utilities, etc.). Despite the growth of Arauca's per capita income above the national average, this economic improvement was also accompanied by a dramatic increase in violence, corruption, and environmental degradation, phenomena which dramatically eroded the quality of life for almost citizen in the department in immeasurable ways ${ }^{63}$.

Thus, there was greater support (or less opposition) to the paramilitary/state incursion in the plains area of Tame and Arauca municipality largely because guerrilla rule was seen by many to be excessively predatory in economic terms, not to mention too restrictive in a social fashion. Whereas the insurgents did not employ extortion or kidnapping for ransom in the piedmont, these activities were regularly employed against recalcitrant cattle ranchers and large landholders in the plains region. These constituencies also stood to benefit greater from

The discovery of oil in the region forced what little military personnel there was to protect the pipeline at the expense of combating insurgents elsewhere in the department. Two decades later, this priority appears to have changed slightly but not much (Interview 26, Bogotá D.C., 2016). In response to the lack of a military reaction to a wave of violence against the civilian population in late 2002, thengovernor Carlos Eduardo Bernal said quite resignedly, “The army's priority is guarding the pipeline” (El Tiempo, 08/02/2002). Interview 8, Arauca (2016); Interview 20, Saravena (2016).

64 A widely held belief throughout the department is that the main, overriding 
a political reconfiguration which took municipal and departmental budgets away from politicians beholden to the insurgents instead of placing them at their own disposal. In the piedmont, however, this project was perceived as favoring external elite interests such as domestic and international oil companies while increasing insecurity and repression at their expense, hence the lack of support and outright opposition to the state expansion campaign in municipalities such as Arauquita, Saravena, Fortul, and part of Tame ${ }^{64}$.

A key factor in explaining this dichotomy of attitudes towards the Colombian state between the disparate regions of Arauca is the distribution of land and the socio-economic makeup of both the piedmont and the plains society. Whereas the plains have historically been dependent on cattle ranching, a trade which concentrates land ownership in the hands of a few, thus creating landed elites, the piedmont was settled by migrants who worked on considerably smaller plots of land cultivating a variety of crops $^{65}$. The key difference here is that the substantially higher level of inequality found in the plains region established a local

objective of the massive state intervention in Arauca was to ensure the continued, and increased production of oil by various domestic and foreign firms at a time when international prices were higher than ever before. In 2002 Occidental Petroleum was on the verge of ending its operations in Colombia due to the massive level of attacks and economic risk its operations were facing in Arauca (Interview 47, Bogotá D.C., 2016). This corresponds with the oft-heard assertion that Uribe's security policies raised investor confidence in the region, and was one key reason why they were implemented in the first place (Interview 25, Tame, 2016).

65 Generally speaking, there are no large landholders in the Araucan piedmont, whereas there are cattle ranchers and other rural elites in the plains region of the department who have tracts of land measuring in the tens of thousands of hectares. These disparate dynamics are reflected by the Gini coefficients for land concentration in Arauca municipality, Arauquita, and Tame in 2000 and 2009. They are as follows: Arauca 0.82 (2000), 0.77 (2009); Arauquita 0.45 (2000), 0.54 (2009); Tame 0.90 (2000), 0.88 (2009). During this period of time, the national averages were 0.81 (2000) and 0.85 (2009). (Sarmiento 2015) 
elite who was not particularly enamored with the redistributive ideology of the ELN or the Farc; hence, they looked for local and external allies such as the armed forces and paramilitaries to help protect their interests. Local elites in the Colombian context tend to be quite opportunistic and they will always defect to the best or most viable option when it presents Itself. ${ }^{66}$

While speaking in generally terms, this statement is particularly true of how Araucan plains elites defected to the state between 2001 and 2003, a crucial decision which enabled the territorial consolidation of the state in this region. Quite simply, the economic dependence of nonelites on larger landholders in the plains demanded a certain level of subservience or acquiescence to this elite agenda and thereby made the forging of linkages between the guerrillas and the civilian population substantial more difficult in this respect. Therefore, non-elites effectively defect when local elites do, albeit in an involuntary and non-visible way. In the piedmont, the lack of these local elites and greater level of economic equality between its inhabitants fostered stronger horizontal linkages to the insurgent groups and thus a greater opposition to external prerogatives in the region such as the exploration and production of oil by domestic and foreign multinationals. ${ }^{67}$

mantener la hegemonía y exclusividad del poder regional o como una manera expedita y fácil de recuperarlo allí donde lo han perdido a manos de grupos de oposición o movimientos cívicos, populares o camp[esinos." (González, Bolívar, and Vásquez 2003: 61)

67 While there is a marked difference between those areas of Arauca which were 'pacified' by the joint paramilitary-state intervention beginning in 2001-2002, and those which were not, it would be tempting to chalk down the success of the ELN and the Farc - not to mention of local communities - to resist this massive effort in the piedmont to the simple fact that areas of resistance are found in colonization zones. While historically insurgent groups cultivated strong linkages with the peasantry in these regions and therefore maintained a high level of influence and control, this in itself is not enough to explain the dichotomy of results found in the piedmont and the plains of Arauca. One only needs to look at the mixed success of the symbiotic state-paramilitary incursion into other colonization zones (i.e. 
In other words, armed columns from the same guerrilla fronts, whether Domingo Laín of the ELN or the $10^{\text {th }}$ and $45^{\text {th }}$ fronts of the Farc, faced different challenges in embedding themselves in varying communities depending entirely on the social and historical composition of the local context ${ }^{68}$. For example the $10^{\text {th }}$ front and Domingo Laín established far deeper vertical linkages, and by extension, a much more totalitarian presence in Gaitán, Arauquita, than in Caracol, Arauca municipality. Whereas the former vereda is characterized by a horizontal class structure with no local elites, the latter possesses a vertical class structure with large landholders and cattle ranchers at one end of the spectrum, with peasants at the other. Unsurprisingly, insurgents from both armed groups established what Anoop Sarbahi terms 'anchored' relations in Gaitán, maintaining a high level of daily interaction and control over almost every aspect of local activity and social interaction, including a high degree of influence over local civil society and politics. In Caracol, on the other hand, these same insurgents forged a 'floating' presence, one characterized by intermittent appearances and interactions with local habitants, albeit with a far less constructive (and intrusive) role in their daily lives. Local involvement in civic life and politics was considerably lower than in Gaitán ${ }^{69}$. Hence, both the state, and more so the paramilitaries, found it exponentially more difficult to penetrate,

Urabá, El Ariari, Putumayo, Catatumbo) to realize that the dynamics of conflict in such regions are more complex than merely chalking up success or defeat to the historical settlement patterns of the land.

This is reflected in the comments of a former Arauquita mayor and congresswoman: "Antes del petróleo esto estaba muy descuidado. Por eso es que nosotros tenemos relación con la guerrilla, porque antes del petróleo la autoridad aquí era la guerrilla." (Interview 15, Arauquita, 2016)

69 Sarbahi (2014) makes a crucial distinction between guerrilla-civilian relations, albeit with a typology which only functions for groups at the national level. 'Anchored' insurgent groups are those groups which "emerge from powerful preexisting political parties that undertook extensive political mobilization during the period preceding the launch of a rebellion" and which "have a high degree of embeddedness in the catchment population and are better able to withstand a disproportionately powerful state". "Floating" groups on the other hand are those 
let alone control territory in the department that was under the sway of anchored insurgent columns, while floating rebel units were quickly dispersed elsewhere, or outright defeated militarily.

\section{Conclusion}

From 2002 until 2010, the Colombian department of Arauca was turned into a laboratory of war by Álvaro Uribe Velez, arguably the most bellicose president in the South American country's history. During this time, the Colombian military - and by extension the state - was able to reclaim certain key territorial and administrative control in Arauca municipality and Tame due to the ability of external-local elite alliances to disrupt the linkages between civil society, local politics, and armed insurgents. However, the high level of embeddedness found in the piedmont civilian population, a product of converging historical processes, ultimately prevented peasants and civil society leaders alike from defecting en masse to the state, a prerequisite which is required to consolidate territorial and bureaucratic control in such contested space. Similarly, the vertical linkages established by both the ELN and the Farc's differing fronts in the piedmont were sufficiently anchored in local social networks to withstand the massive state-paramilitary offensive throughout Arauca until a more flexible commander-in-chief assumed the presidency in mid-2010. The lack of such ties in the plains region of Arauca municipality and Tame saw the expulsion of the insurgents and a social reconfiguration of said space. However, despite shedding light on some original causal explanations for state and insurgent capacity to maintain control of territory in contested spaces, these avenues require further exploration to fully be incorporated to a working theory or model in the study of micro-level violence and internal conflict.

which "lack social embeddedness" and are "unconstrained by the catchment population" and, hence, tend to be "usually unresponsive to societal calls and invariably stick to their maximalist goals" (2014: 1474). 
In the context of the recent electoral rejection of the plebiscite between the Colombian government and the Farc, the future stability of Arauca looks highly uncertain. With oil revenues at a recent low, and the inevitable exhaustion of the department's oil reserves within the next decade, the economic viability of Arauca is more vulnerable than it has ever been in recent history. The fact that Arauca is also home to the ELN's strongest and most bellicose guerrilla front in the entire country, not to mention two active and very capable Farc fronts as well, makes for a potential powder keg in the Eastern plains. This is particularly salient in light of the fact that the Farc will almost certainly be looking to regain lost territory and influence in areas of the department where the ELN has expanded and consolidated control as a result of the recent negotiations with the Santos administration. In such a context, these groups increasingly run the risk of becoming armed non-state actors who continue to exist due to the simple fact that "one side is not strong enough to win and the other is not weak enough to lose" (Kalyvas 2006: 67). Hence, it is quite plausible, in this scenario, that both the ELN and the Farc in Arauca, while maintaining such high levels of territorial and population control in the piedmont region, will "no longer seek or even need to establish territorial, bureaucratic or consent based political authority in the traditional sense" (Duffield 1998: 76), thereby converting into retreating insurgencies. This development would ultimately indicate a blurring of lines between former adversaries which prioritizes resource extraction rather than control over territory and population.

\section{References}

Amnistía Internacional. (2004). Colombia-Un laboratorio de Guerra: Represión y violencia en Arauca. Retrived from http://www.acnur.org/t3/uploads/media/ COI_351.pdf

Bakke, K.M., Gallagher Cunningham K. \& Seymour L. (2012). A Plague of Initials: Fragmentation, Cohesion, and Infighting in Civil Wars. Perspectives on Politics, 10(2), 265-283.

Ravi, B., Miodownik, D. \& Choi, H.J. (2011). Violence and Control in Civil Conflict: Israel, the West Bank, and Gaza. Comparative Politics, 44(1), 61-80. 
C. López Hernández (Coord.) (2010) Monografía Político Electoral. Departamento de Arauca 1997 a 2007, Bogotá: Misión de Observación Electoral,

Carroll, L. (2011). Violent Democratization: Social Movements, Elites, and Politics in Colombia's Rural War Zones, 1984-2008. : South Bend, United States of America: University of Notre Dame Press.

Colletta, N.J. \& Cullen, M.L. (2000). The Nexus between Violent Conflict, Social Capital and Social

Cohesion: Case Studies from Cambodia and Rwanda., Washington D.C.: World Bank.

Defensoría del Pueblo. (2003). Proyecto Apoyo Defensorial en Las Zonas de Rehabilitación y Consolidación. Primer Informe de Actividades. Retrived from http://www.defensoria.gov.co/attachment/52/Proyecto \% 20apoyo $\% 20$ defensorial \% 20de \% 20las \% 20zonas \% 20de\% 20rehabilitaci \% C3 \% B3n \% 20 y\%20consolidaci \% C3 \% B3n.pdf

El Tiempo. (2002, august 2nd). Arauca se inunda de coca. El Tiempo, Retrived from http://www.eltiempo.com/archivo/documento/MAM-1351780

González, F., Bolívar, I. \& Vásquez T. (2003). Violencia Política en Colombia. De la nación fragmentada a la construcción del Estado. Bogotá: CINEP.

Granovetter, M. (1985). Economic Action and Social Structure: The Problem of Embeddedness. American Journal of Sociology, 91, 481-510.

Gutiérrez Loaiza, A. (2012). Negociaciones de paz en Colombia, 1982-2009. Un estado del arte. Estudios Políticos, 40, 175-200.

Gutiérrez Lemus, O.J. (2010). Arauca: Espacio, conflicto e institucionalidad. Análisis Político, 69, 3-34.

Gutiérrez-Sanín, F. (2008). Telling the Difference: Guerrillas and Paramilitaries in the Colombian War. Politics Society, 36(3), 3-34.

Humphreys, M. \& Weinstein, J. (2006). Handling and Manhandling Civilians in Civil War. American Political Science Review, 100(3), 429-447.

Idler, A. (2012). Exploring Arrangements of Convenience among Violent Nonstate Actors. Perspectives on Terrorism, 6(4-5), 63-84. 
“Interview 1.” Personal Interview. Bogotá D.C., 18 Jan. 2016.

“Interview 4.” Personal Interview. Arauca, 20 Jan. 2016.

“Interview 8.” Personal Interview. Arauca, 22 Jan. 2016.

“Interview 12.” Personal Interview. Arauquita, 24 Jan. 2016.

“Interview 13.” Personal Interview. Arauquita, 24 Jan. 2016.

“Interview 14.” Personal Interview. Arauquita, 24 Jan. 2016.

“Interview 15.” Personal Interview. Arauquita, 25 Jan. 2016.

“Interview 16.” Personal Interview. Saravena, 26 Jan. 2016.

“Interview 17.” Personal Interview. Saravena, 26 Jan. 2016.

“Interview 18.” Personal Interview. Saravena, 26 Jan. 2016.

“Interview 19.” Personal Interview. Saravena, 27 Jan. 2016.

“Interview 20.” Personal Interview. Saravena, 27 Jan. 2016.

“Interview 21.” Personal Interview. Saravena, 28 Jan. 2016.

“Interview 22.” Personal Interview. Fortul, 28 Jan. 2016.

“Interview 23.” Personal Interview. Fortul, 28 Jan. 2016.

“Interview 24.” Personal Interview. Saravena, 29 Jan. 2016.

“Interview 25.” Personal Interview. Tame, 30 Jan. 2016.

“Interview 47.” Personal Interview. Bogotá D.C., 26 April 2016.

Kalyvas, S. (2006). The Logic of Violence in Civil War. United Kingdom: Cambridge University Press.

Kline, H.. (2009). Showing Teeth to the Dragons: State-Building by Colombian President Álvaro Uribe Vélez, 2002-2006. Tuscaloosa, United States of America: The University of Alabama Press.

Leal Buitrago, F. (2006). La política de seguridad democrática 2002-2005. Análisis Político, 57, 3-30. 
Levitsky, S \& Lucan, W. (2013). The Durability of Revolutionary Regimes. Journal of Democracy, 24(3), 5-17.

Peñate, E. (1998). El sendero estratégico del ELN: del idealismo guevarista al clientelismo armado. Documento de Trabajo No. 15. Bogotá: Universidad de Los Andes.

Portes, A. (2010). Economic Sociology: A Systemic Inquiry. Princeton: Princeton University Press.

Portes, A. \& Sensenbrenner J. (1993). Embeddedness and Immigration: Notes on the Social Determinants of Economic Action. The American Journal of Sociology, 98(6), 1320-1350.

Raleigh, C. \&. Dowd, C. (2013). Governance and Conflict in the Sahel's 'Ungoverned Space'. Stability: International Journal of Security \& Development, 2(32), 1-17.

Sarbahi, A. (2014). Insurgent Population Ties and the Variation in the Trajectory of Peripheral Civil Wars. Comparative Political Studies, 47(10) 14701500 .

Sarmiento, L. (2015). Arauca 1983-2015: Fin de un ciclo histórico y transición incierta. Bogotá: Fundación Paz y Reconciliación. Retrived from http:// revistacepa.weebly.com/uploads/1/3/3/7/13372958/araucaypetroleolibardosarmiento.pdf

Semana. (January 19 2009). Cómo el Ejército se alió con el ELN en Arauca. Semana. Retrived from http://www.semana.com/nacion/articulo/comoejercito-alio-eln-arauca/99226-3

Staniland, P. (2012). States, Insurgents, and Wartime Political Orders. Perspectives on Politics, 10(2), 243-264.

Staniland, P. (2014). Networks of Rebellion: Explaining Insurgent Cohesion and Collapse. Ithaca, Cornell University Press.

Sweig, J.E. (2002). What Kind of War for Colombia?. Foreign Affairs, 81(5), 122-141.

United States Government Accountability Office. (2011). Security Assistance: Efforts to Secure Colombia's Caño-Limón-Coveñas Oil Pipeline Have Redu- 
ced Attacks, But Challenges Remain. Report to Congressional Requesters (2005)

Vargas, G. (2009). Urban Irregular Warfare and Violence against Civilians: Evidence from a Colombian City. Terrorism and Political Violence, 21, 110-132.

Weinstein, J. (2006). Inside Rebellion: the Politics of Insurgent Violence. United Kingdom: Cambridge University Press. 